\title{
Effect of Different Soaking Period of Plant Extracts as Seed Treatment to Manage Seed Mycoflora of Okra
}

\author{
Praveen Banvasi*, C.P. Khare, G. K. Awadhiya, Veer Singh, \\ Dheeraj Baghel and Varsha Kerketta
}

Department of Plant Pathology, Indira Gandhi Krishi Vishvavidhalaya, Raipur, (CG), 492012, India

*Corresponding author

\section{Keywords}

Soaking period, Plant extracts, Seed treatment, Seed mycoflora, Okra

\section{Article Info}

\section{Accepted:}

15 April 2020

Available Online:

10 May 2020

\section{A B S T R A C T}

The experiment was conducted to know the effect of four plant extracts viz. neem, garlic, Cassia tora, and ginger extract were used for different soaking period 0, 1/2, $1,2,3,4,5$ hours) for testing the efficacy of plant extract against seed mycoflora of okra. In different plant extract average highest germination was observed in neem extract treated okra seed $67.32 \%$ followed by garlic $(64.10 \%)$, Cassia tora $(61.60 \%)$ and lowest was in ginger extract treated seed $(54.64 \%)$, in case of soaking period average highest germination was observed in five hours of soaking period $(74.69 \%)$ followed by four hours $(73.13 \%)$, three hours $(69.69 \%)$, two hours $(61.56 \%)$, one hours $(55.94 \%)$, half hours $(50 \%)$ and lowest germination was observed in zero hours of soaking period (48.44\%). In different plant extract average highest mycoflora was observed in garlic extract treated okra seed (32.86 $\%$ ) followed by ginger $(32.32 \%)$, Cassia tora $(31.40 \%)$ and lowest was in neem extract treated seed $(29.46 \%)$, in case of soaking period average highest mycoflora was observed in zero hours of soaking period $(35.31 \%)$ followed by three hours $(33.43 \%)$, one hours $(31.56 \%)$, two hours $(30.93 \%)$, half hours $(30.93 \%)$, five hours $(29.37 \%)$ and lowest mycoflora was observed in four hours of soaking period $(29.06 \%)$.

\section{Introduction}

Okra (Abelmoschus esculentus; family Malvaceae) is grown in temperate as well as subtropical regions of the world, both for human consumption as a vegetable and for industrial uses. Hence, it is classified as a warm season crop (National Research Council, 2006). The major okra producing countries in the world include India (6.35 million tons), Nigeria (1.10 million tons), Iraq (0.14 million tons), Côte d'Ivoire (0.13 million tons) and Pakistan (0.10 million tons) (Anonymous 2013). India is largest producer 
of okra in the world with total area of 0.53 million hectares and the productivity of the crop is 11.9 MT (Anonymous 2013-14). Nutritional profile of okra showed that it contains saturated fats, carbohydrates, proteins, vitamin A, B6, B12, folate, ribofalvin, niacin, pentothenic acid, Vitamin $\mathrm{C}$, and $\mathrm{E}$ etc., it also contains magnesium, phosphorous, potassium, zinc, sodium, copper, manganese and selenium. The seeds also contains dietary fiber and sugars (Anon., 2012). The mucilage from okra is suitable for industrial and medicinal application and could be applied as plasma replacement or blood volume expander (Arapitsas, 2008). The leaf buds and flowers are also edible. The seed when roasted and ground can be used as coffee additive or substitute (Moekchantuk and Kumar, 2004). The roots and stems of okra are used for clarification of sugarcane juice from which gur or brown sugar is prepared (Chauhan, 1972). Its medicinal value has also been reported in curing ulcers and relief from haemorrhoids (Adams, 1975). Okra seeds contain a considerable amount of good quality oil and protein and can be used as a substitute for coffee (Valeriana, 2002).

Various factors are responsible for low yield of okra. Seed-borne fungal diseases are often the main cause. In most regions of the world, okra crop is produced in large quantities, poor agronomic practices and storage conditions including improper drying and inadequate structures have contributed to the reportedly high prevalence of fungal contaminants of okra especially seed-borne molds. So, management of these seed-borne fungi is very important to produce okra successfully. As there is no resistant variety, so control of these fungi through host resistance in not possible. Again control of these seed-borne fungi using chemicals increase production cost and causes environmental pollution. Plant extracts had shown good results as seed treating agent. Considerable amount of study have been done with chemical fungicide to control seed-borne disease of okra (Akter, 2008 and Ahmed, 2011). But a few studies were done to control the seed-borne fungi of okra using plant extracts. For these reasons, three plant extracts have been used in this experiment viz. garlic extract, ginger extract, Cassia tora extract and neem extracts as seed treating agent.

\section{Materials and Methods}

The experiment was conducted during the period of Kharif and Rabi season of 2016-17. For the testing of efficacy of plant extract following plants was used for seed treatment Azadirachta indica, Allium sativum, Cassia tora and Zingiber officinale. The collected plant parts were chopped after cleaning under running tap water. The extracts were prepared by crushing the plant parts in a blender or mortar and pestle with distilled water at 1:2 (100 g crushed plant materials in $200 \mathrm{ml}$ water). Later extract was boiled for 15 minutes then properly shacked with shaker. The extracts were filtered through cheese cloth and kept in conical flask. The extracts thus obtained were kept in a refrigerator at $4 \pm 1^{\circ} \mathrm{C}$ until use. Seed samples were treated following dipping method.

The seeds were dipped into previously prepared dose of neem, garlic, sickle pod and ginger extracts for different soaking period at the rate of $0,1 / 2,1,2,3,4$, and 5 hours @ 1:1 ratio (sterilized water and plant extract). After proper covering of the seed coat with the extracts the remaining examined plants extracts were drained out from the petridishes and seeds were dried in air for some time by keeping on sterilized blotter paper. After incubating the treated seeds, the fungi yielded were observed and germination of seeds was counted. The treated seeds were examined following the standard blotter method (ISTA, 1999). 


\section{Results and Discussion}

\section{Effect of different soaking period of plant extracts on seed germination of okra}

In different plant extract average highest germination was observed in neem extract treated okra seed $67.32 \%$ followed by garlic (64.10\%), Cassia tora (61.60\%) and lowest was in ginger extract treated seed (54.64\%),in case of soaking period average highest germination was observed in five hours of soaking period $(74.69 \%)$ followed by four hours $(73.13 \%)$, three hours $(69.69 \%)$, two hours $(61.56 \%)$, one hours $(55.94 \%)$, half hours $(50 \%)$ and lowest germination was observed in zero hours of soaking period $(48.44 \%)$.

In case of soaking period, neem extract treated seeds germination was highest $(78.75$ $\%$ ) in 5 hrs. soaking period followed by 77.5 $\%$ in 4 hrs. soaking period, $76.25 \%$ in $3 \mathrm{hrs}$. soaking period, $62.5 \%$ in 1 hrs. soaking period, $55 \%$ in $1 / 2$ hrs. soaking period and lowest germination was $50 \%$ in 0 hrs. soaking period, In Garlic extract treated seed. germination was highest $(76.25 \%)$ in both 4 hrs. and 5 hrs. soaking period followed by $72.5 \%$ in 3 hrs. soaking period, $61.25 \%$ in 2 hrs. soaking period, $56.25 \%$ in $1 \mathrm{hrs}$. soaking period $53.75 \%$ in $0 \mathrm{hrs}$. soaking period and lowest germination was $52.5 \%$ In $1 / 2 \mathrm{hrs}$. soaking period, seed treated with Cassia tora extract was found highest $78.75 \%$ germination in $4 \mathrm{hrs}$. soaking period followed by $76.25 \%$ in 5 hrs. soaking period, $72.5 \%$ in $3 \mathrm{hrs}$. soaking period, $57.5 \%$ in $2 \mathrm{hrs}$. soaking period, $56.25 \%$ in $1 \mathrm{hrs}$. soaking period and lowest $45 \%$ in both $1 / 2 \mathrm{hrs}$. and 0 hrs. soaking period, In ginger extract treated seed germination was highest $67.5 \%$ in 5 hrs. soaking period followed by $60 \%$ in $4 \mathrm{hrs}$. soaking period, $57.5 \%$ in $3 \mathrm{hrs}$ soaking period, $56.25 \%$ in $1 \mathrm{hrs}$. soaking period, 47.5 $\%$ in $1 / 2$ hrs. soaking period and lowest germination was $45 \%$ in 0 hrs soaking period. In control condition germination was highest in neem extract treated seed $(48.5 \%)$ followed by Cassia tora extract treated seed $(47.5 \%)$, garlic extract treated seed $(45 \%)$ and lowest germination was ginger extract treated seed $(42 \%)$,(Table 1$)$.

\section{Effect of botanical extract on mycoflora of okra}

In different plant extract average highest mycoflora was observed in garlic extract treated okra seed $(32.86 \%)$ followed by ginger (32.32\%), Cassia tora $(31.40 \%)$ and lowest was in neem extract treated seed $(29.46 \%)$, in case of soaking period average highest mycoflora was observed in zero hours of soaking period $(35.31 \%)$ followed by three hours $(33.43 \%)$, one hours (31.56\%), two hours $(30.93 \%)$, half hours (30.93\%), five hours $(29.37 \%)$ and lowest mycoflora was observed in four hours of soaking period $(29.06 \%)$.

In case of soaking period, in neem extract treated seeds mycoflora was highest $(35 \%)$ in $3 \mathrm{hrs}$. soaking period followed by $32.5 \%$ in $1 / 2$ hrs. soaking period, $31.25 \%$ in both $0 \mathrm{hrs}$. and 4 hours soaking period, $27.5 \%$ in 5 hrs. soaking period, $25 \%$ in $2 \mathrm{hrs}$. soaking period and lowest mycoflora was $23.75 \%$ in $1 \mathrm{hrs}$. soaking period, in Garlic extract treated seed. mycoflora was highest $(36.25 \%)$ in 0 hrs. soaking period followed by $35 \%$ in $3 \mathrm{hrs}$. soaking period, $33.75 \%$ in 4 hrs. soaking period, $32.5 \%$ in $1 \mathrm{hrs}$. soaking period 31.25 $\%$ in both $1 / 2$ hrs. and 2 hrs. soaking period and lowest mycoflora was $30 \%$ In $5 \mathrm{hrs}$. soaking period, seed treated with Cassia tora extract was found highest $38.75 \%$ mycoflora in $0 \mathrm{hrs}$. soaking period followed by $37.5 \%$ in 2 hrs. soaking period, $33.75 \%$ in 1 hrs. soaking period, $28.75 \%$ in $3 \mathrm{hrs}$. soaking period, $27.5 \%$ in $1 / 2$ hrs. soaking period, $30 \%$ in $5 \mathrm{hrs}$. soaking period and lowest $23.75 \%$ in 
4 hrs. soaking period, In ginger extract treated seed mycoflora was highest $36.25 \%$ in $1 \mathrm{hrs}$. soaking period followed by $35 \%$ in both 3 hrs. and 0 hrs. soaking period, $32.5 \%$ in $1 / 2$ hrs soaking period, $30 \%$ in both 2 hrs. and 5 hrs. soaking period, and lowest mycoflora was $27.5 \%$ in 4 hrs soaking period. In control condition mycoflora was highest in ginger extract treated seed $(87.5 \%)$ followed by neem extract treated seed ( $85 \%)$, and lowest mycoflora was found in both Cassia tora and garlic extract treated seed $(80 \%)$.(Table 2$)$.

Similar research were done by some earlier workers (Fakir et al., (1977), Neergaard (1979) Fakir (1982), Gupta et al., (1989), Fakir (2000), Jamandar et al., (2001), Roy et al., ( 2012), Shekhawat and Prasada (1971), Khaleduzzaman (1996) and Islam (2004).

In different soaking period of neem seed extract highest frequency of mycoflora was recorded in three hours (35\%) viz. Fusarium sp.(13.75\%), Aspergillus flavus (12.5\%), Chaetomium sp.(1.25\%), Alternaria sp.(3.75\%), Rhizopus sp.(1.25\%) and Nigrospora sp.(2.5\%), and lowest frequency was in one hour soaking period $(23.75 \%)$ viz. Fusarium sp.(7.5\%), Aspergillus flavus (13.75\%), Alternaria sp.(2.5\%).

Fusarium sp. was highest (13.75\%) in 2 hrs., $3 \mathrm{hrs}$. and $5 \mathrm{hrs}$. soaking period followed by $11.25 \%$ in $1 / 2 \mathrm{hrs}$. and $4 \mathrm{hrs}$. soaking period, $8.75 \%$ in 0 hrs. soaking period and lowest 7.5 $\%$ was in $1 \mathrm{hrs}$. soaking period. Aspergillus flavus was highest $16.25 \%$ in 0 hrs. soaking period followed by $13.75 \%$ in 1 hrs. soaking period, $12.5 \%$ in $1 / 2$ hrs. and 3 hrs. soaking period, $11.25 \%$ in 4 hrs. soaking period and lowest $8.75 \%$ in 2 hrs. and 5 hrs. soaking period, Chaetomium sp. was highest $3.75 \%$ in $0 \mathrm{hrs}$. soaking period followed by $2.5 \%$ in $4 \mathrm{hrs}$. soaking period and lowest was $1.25 \%$ in $1 / 2$ hrs., 2 hrs., 3 hrs. and 5 hrs. soaking period and was not found in 1 hrs. soaking period, Alternaria sp. was highest (5\%) in 4 hrs. soaking period followed by $3.75 \%$ in 3 hrs. soaking period, $2.5 \%$ in 0 hrs., $1 / 2 \mathrm{hrs}$. and 1 hrs. soaking period and lowest was 1.25 $\%$ in $5 \mathrm{hrs}$. soaking period and not found in 2 hrs. soaking period, Rhizopus sp. (1.25\%) was found in both $3 \mathrm{hrs}$. and $4 \mathrm{hrs}$. soaking period, Nigrospora sp. (2.5\%) was found in $1 / 2 \mathrm{hrs}$. and $3 \mathrm{hrs}$. soaking period, Sterile mycelium was found highest $(2.5 \%)$ in $1 / 2 \mathrm{hrs}$. and 5 hrs. soaking period and lowest $1.25 \%$ was in 2 hrs. soaking period. In control condition frequency was highest of Fusarium sp. (31 \%),followed by Aspergillus flavus (22.5\%), Alternaria sp. and sterile mycelium (7.5\%), Chaetomium sp. and Nigrospora sp. (5\%) and lowest was Rhizopus sp. (2.5\%).

On an average among all the soaking period of neem extract Aspergillus flavus (11.96\%) was recorded highest followed by Fusarium sp. (11.42 \%), Alternaria sp. $(2.5 \%)$, Chaetomium sp.(1.60\%), Nigrospora sp.(0.71 $\%)$ and lowest was Rhizopus sp. (0.35\%) (Table 3). Also corroborates with the the findings of some earlier workers (Ambekar et al., (2000), Zaman et al., (1997), Hossain (2001), Singh and Kumar (2003), Abduhu (2007), Islam (2004), Islam (2006), Islam (2012) and Zaman et al., (1997).

Seed soaking in different duration (hrs.) in neem extract did not show any significance in controlling microbial frequencies.

In different soaking period of garlic extract highest frequency of mycoflora was recorded in Zero hours $(36.25 \%)$ viz. Fusarium sp.(15\%), Aspergillus flavus (15\%), Alternaria sp.(2.5\%), Curvularia sp. $(2.5 \%)$ and sterile mycelium (1.25\%), and lowest frequency was in five hour soaking period (30\%) viz. Fusarium sp.(13.75\%), Aspergillus flavus (11.25\%), Alternaria sp. (1.25\%) and sterile mycelium $(3.75 \%)$. 
Aspergillus flavus was highest $15 \%$ in $0 \mathrm{hrs}$., $1 / 2 \mathrm{hrs}$., $3 \mathrm{hrs}$., and 4 hrs. soaking period, 12.5 $\%$ in 1 hrs. and 2 hrs. soaking period and lowest was $11.25 \%$ in 5 hrs. soaking period, Fusarium sp. was highest $15 \%$ in 0 hrs. concentration followed by $13.75 \%$ in $1 / 2 \mathrm{hrs}$. and 5 hrs. soaking period, $12.5 \%$ in 2 hrs., 3 hrs., and 4 hrs. soaking period and lowest was $11.25 \%$ in 1 hrs. soaking period, Curvularia $s p$. was highest $2.5 \%$ in 0 hrs. soaking period and lowest was $1.25 \%$ in $1 \mathrm{hrs}$. and $3 \mathrm{hrs}$. soaking period nd not found in $1 / 2 \mathrm{hrs}$., $2 \mathrm{hrs}$., $4 \mathrm{hrs}$. and 5 hrs. soaking period, steril mycelium was highest $3.75 \%$ in 5 hrs. and 2hrs. soaking period and lowest was $1.25 \%$ in $0 \mathrm{hrs}$. and $3 \mathrm{hrs}$. soaking period and not found in $1 / 2 \mathrm{hrs}$., $1 \mathrm{hrs}$. and $4 \mathrm{hrs}$. soaking period, Alternaria sp. was highest (5\%) in 1 hrs. and 3 hrs. soaking period followed by 2.5 hrs. in 0 hrs. $2 \mathrm{hrs}$. and $4 \mathrm{hrs}$. soaking period and lowest was $(1.25 \%)$ in 5 hrs. soaking period, Chaetomium sp. was $3.75 \%$ in $4 \mathrm{hrs}$. soaking period and lowest $(2.5 \%)$ was in $1 / 2$ hrs. and 1 hrs. soaking period and not found in 0 hrs., 2hrs., 3hrs. and 5 hrs. soaking period Memnoniella sp.(5\%) and Rhizopus sp. (2.5 $\%$ ) was observed only in control condition.

Aspergillus flavus was highest in control condition followed by Fusarium sp. (17.5\%), sterile mycelium (12.5\%), Alternaria sp. (10 $\%)$, Chaetomium sp. (7.5\%), Curvularia sp. and Memnoniella sp. (5\%) and lowest was Rhizopus sp.(2.5\%). Among all different soaking period on an average Aspergillus flavus (13.75\%) was found highest followed by Fusarium sp. (13.04 \%), Alternaria sp.(2.68\%), Sterile mycelium (1.43\%), Chaetomium sp. (1.25\%) and lowest was Curvularia sp. (0.71 \%) (Table 4). Similar results were reported by (Akter, 2008). However, garlic extract used in controlling seed-borne infection of different crops showed that garlic extract was a potential agent to control the seed-borne pathogens of different vegetable crops (Zaman et al., 1997 and Hossain, 2001). It is also corroborated the result in case of other crops (Rahman et al., 1999, Anonymous, 2004 and Sultana, 2009).

Seed soaking in different duration (hrs.) in garlic extract did not show any significance in controlling microbial frequencies.

In different soaking period of Cassia tora extract, highest frequency of mycoflora was recorded in zero hours treatment $(38.75 \%)$ viz. Fusarium sp.(12.5\%), Aspergillus flavus (20\%), Alternaria sp.(2.5\%), Chaetomium sp. $(1.25 \%)$ and sterile mycelium $(2.5 \%)$, and lowest frequency was in four hour soaking period (23.75\%) viz. Fusarium sp.(11.25\%) and Aspergillus flavus (12.5\%).

Aspergillus flavus was highest $20 \%$ in $0 \mathrm{hrs}$. soaking period followed by $17.5 \%$ in $2 \mathrm{hrs}$. soaking period, $15 \%$ in $1 \mathrm{hrs}$. and $3 \mathrm{hrs}$. soaking period, $13.75 \%$ in 1 hrs. soaking period and lowest was $12.5 \%$ in $4 \mathrm{hrs}$. and 5 hrs. soaking period, Sterile mycelium was highest $2.5 \%$ in $0 \mathrm{hrs}$. and lowest was $1.25 \%$ in 2 hrs. soaking period and not found in $1 / 2$ hrs., 1 hrs., 3 hrs., 4 hrs., and 5 hrs. soaking period , Fusarium sp. was highest $16.25 \%$ in 5 hrs. soaking period followed by $15 \%$ in 2 hrs. soaking period, $13.75 \%$ in 1 hrs. soaking period $12.5 \%$ in $0 \mathrm{hrs}$. and $3 \mathrm{hrs}$. soaking period, $11.25 \%$ in $4 \mathrm{hrs}$. soaking period and lowest was $10 \%$ in $1 / 2$ hrs. soaking period, Alternaria sp. was highest $(5 \%)$ in $1 \mathrm{hrs}$. soaking period followed by $3.75 \%$ in $1 / 2 \mathrm{hrs}$. soaking period, $2.5 \%$ in $0 \mathrm{hrs}$. and $2 \mathrm{hrs}$. soaking period and lowest $1.25 \%$ in $3 \mathrm{hrs}$. and 4 hrs. soaking period and not found in 4 hrs. soaking period, Chaetomium sp. was found only in 0 hrs. soaking period and Curvularia sp. was found only in $2 \mathrm{hrs}$. soaking period.

Fusarium sp. was found highest (27.77\%) in control condition followed by Aspergillus flavus (25\%), Alternaria sp. (12.5\%), 
Chaetomium sp.(10\%), Steril mycelium (7.5 $\%$ ) and lowest was Curvularia sp. (5 \%). Among different soaking period of plant extract average highest frequency of mycoflora was Aspergillus flavus (15.17\%) followed by Fusarium sp. (13.03\%), Alternaria sp. (2.32\%), steril mycelium (0.53 $\%)$ and lowest was Curvularia sp. (0.17\%) and Chaetomium sp. (0.17\%) (Table 5). Similar results were reported by (Akter, 2008).

Seed soaking in different duration (hrs.) in Cassia tora extract did not show any significance in controlling microbial frequencies.

Seed treatment with ginger extract for different soaking period was recorded highest frequency of mycoflora in one hours treatment $(36.25 \%)$ viz. Fusarium sp. (13.75\%), Aspergillus flavus (12.5\%), Alternaria sp.(6.25\%), Curvularia sp. (2.5\%) and sterile mycelium (1.25\%), and lowest frequency was in four hour soaking period $(27.5 \%)$ viz. Fusarium sp. $(8.75 \%)$ and Aspergillus flavus (15\%) and Alternaria $s p .(3.75 \%)$ (Fig. 1-3).

Table.1 Effect of different soaking period on germination of okra seeds

\begin{tabular}{|c|c|c|c|c|c|}
\hline \multirow{3}{*}{$\begin{array}{c}\text { Soaking } \\
\text { period (hours) }\end{array}$} & \multicolumn{4}{|c|}{ Plant extract } & \multirow[t]{3}{*}{ Mean } \\
\hline & Neem & Garlic & Cassia tora & Ginger & \\
\hline & \multicolumn{4}{|c|}{ (Germination \%) } & \\
\hline $\mathbf{0}$ & 50 & 53.75 & 45 & 45 & 48.44 \\
\hline $1 / 2$ & 55 & 52.5 & 45 & 47.5 & 50.00 \\
\hline 1 & 62.5 & 56.25 & 56.25 & 48.75 & 55.94 \\
\hline 2 & 71.25 & 61.25 & 57.5 & 56.25 & 61.56 \\
\hline 3 & 76.25 & 72.5 & 72.5 & 57.5 & 69.69 \\
\hline 4 & 77.5 & 76.25 & 78.75 & 60 & 73.13 \\
\hline 5 & 78.75 & 76.25 & 76.25 & 67.5 & 74.69 \\
\hline Control & 48.5 & 45 & 47.5 & 42 & 45.75 \\
\hline Mean & 67.32 & 64.10 & 61.60 & 54.64 & \\
\hline
\end{tabular}

Table.2 Effect of botanical extract on mycoflora of okra

\begin{tabular}{|c|c|c|c|c|c|}
\hline \multirow{3}{*}{$\begin{array}{c}\text { Soaking } \\
\text { period (hours) }\end{array}$} & \multicolumn{4}{|c|}{ Plant extract } & \multirow[t]{3}{*}{ Mean } \\
\hline & Neem & Garlic & Cassia tora & Ginger & \\
\hline & \multicolumn{4}{|c|}{ Frequency $(\%)$} & \\
\hline $\mathbf{0}$ & 31.25 & 36.25 & 38.75 & 35 & 35.31 \\
\hline $1 / 2$ & 32.5 & 31.25 & 27.5 & 32.5 & 30.93 \\
\hline 1 & 23.75 & 32.5 & 33.75 & 36.25 & 31.56 \\
\hline 2 & 25 & 31.25 & 37.5 & 30 & 30.93 \\
\hline 3 & 35 & 35 & 28.75 & 35 & 33.43 \\
\hline 4 & 31.25 & 33.75 & 23.75 & 27.5 & 29.06 \\
\hline 5 & 27.5 & 30 & 30 & 30 & 29.37 \\
\hline Control & 85 & 80 & 80 & 87.5 & 83.12 \\
\hline Mean & 29.46 & 32.86 & 31.40 & 32.32 & \\
\hline
\end{tabular}


Table.3 Effect of different soaking period in neem extract on seed mycoflora of okra

\begin{tabular}{|c|c|c|c|c|c|c|c|c|}
\hline \multirow{2}{*}{$\begin{array}{l}\text { Soaking } \\
\text { period } \\
\text { (hours) }\end{array}$} & \multicolumn{7}{|c|}{$\begin{array}{l}\text { Recorded mycoflora } \\
(\%)\end{array}$} & \multirow[t]{2}{*}{$\begin{array}{l}\text { Frequency } \\
\text { (\%) }\end{array}$} \\
\hline & 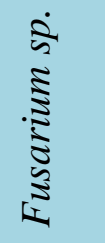 & 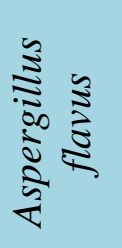 & 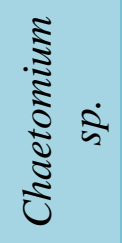 & 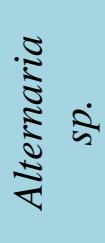 & 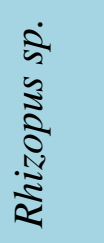 & 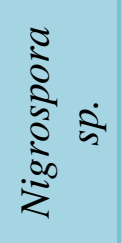 & 兽竞 & \\
\hline 0 & 8.75 & 16.25 & 3.75 & 2.5 & - & - & - & 31.25 \\
\hline $1 / 2$ & 11.25 & 12.5 & 1.25 & 2.5 & - & 2.5 & 2.5 & 32.5 \\
\hline 1 & 7.5 & 13.75 & - & 2.5 & - & - & - & 23.75 \\
\hline 2 & 13.75 & 8.75 & 1.25 & - & - & - & 1.25 & 25 \\
\hline 3 & 13.75 & 12.5 & 1.25 & 3.75 & 1.25 & 2.5 & - & 35 \\
\hline 4 & 11.25 & 11.25 & 2.5 & 5 & 1.25 & - & - & 31.25 \\
\hline 5 & 13.75 & 8.75 & 1.25 & 1.25 & - & - & 2.5 & 27.5 \\
\hline Control & 31 & 22.5 & 5 & 7.5 & 2.5 & 5 & 7.5 & 85 \\
\hline Mean & 11.42 & 11.96 & 1.60 & 2.5 & 0.35 & 0.71 & 0.89 & 29.46 \\
\hline
\end{tabular}

Table.4 Effect of different soaking period in garlic extract on seed mycoflora of okra

\begin{tabular}{|c|c|c|c|c|c|c|c|c|c|}
\hline \multirow{2}{*}{$\begin{array}{l}\text { Soaking } \\
\text { period } \\
\text { (hours) }\end{array}$} & \multicolumn{8}{|c|}{$\begin{array}{c}\text { Recorded mycoflora } \\
(\%)\end{array}$} & \multirow[t]{2}{*}{$\begin{array}{l}\text { Frequency } \\
(\%)\end{array}$} \\
\hline & 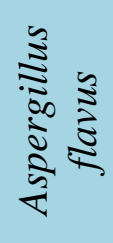 & 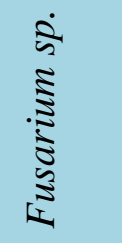 & $\frac{\sqrt{3}}{\sqrt[3]{3}}$ & 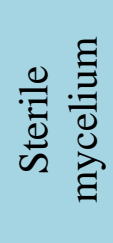 & 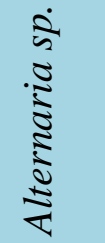 & 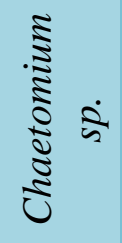 & 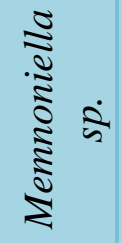 & 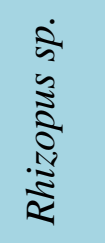 & \\
\hline 0 & 15 & 15 & 2.5 & 1.25 & 2.5 & - & - & - & 36.25 \\
\hline $1 / 2$ & 15 & 13.75 & - & - & - & 2.5 & - & - & 31.25 \\
\hline 1 & 12.5 & 11.25 & 1.25 & - & 5 & 2.5 & - & - & 32.5 \\
\hline 2 & 12.5 & 12.5 & - & 3.75 & 2.5 & - & - & - & 31.25 \\
\hline 3 & 15 & 12.5 & 1.25 & 1.25 & 5 & - & - & - & 35 \\
\hline 4 & 15 & 12.5 & - & - & 2.5 & 3.75 & - & - & 33.75 \\
\hline 5 & 11.25 & 13.75 & - & 3.75 & 1.25 & - & - & - & 30 \\
\hline Control & 20 & 17.5 & 5 & 12.5 & 10 & 7.5 & 5 & 2.5 & 80 \\
\hline Mean & 13.75 & 13.04 & 0.71 & 1.43 & 2.68 & 1.25 & - & - & 32.86 \\
\hline
\end{tabular}


Table.5 Effect of different soaking period in Cassia tora extract on seed mycoflora of okra

\begin{tabular}{|c|c|c|c|c|c|c|c|}
\hline \multirow{2}{*}{$\begin{array}{c}\text { Soaking } \\
\text { period } \\
\text { (hours) }\end{array}$} & \multicolumn{6}{|c|}{$\begin{array}{c}\text { Recorded mycoflora } \\
(\%)\end{array}$} & \multirow[t]{2}{*}{$\begin{array}{c}\text { Frequency } \\
(\%)\end{array}$} \\
\hline & 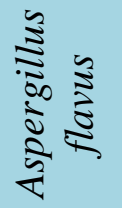 & 离 & 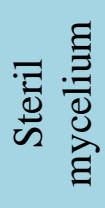 & 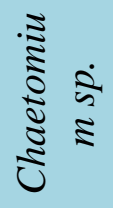 & $\frac{\sqrt{\pi}}{\frac{2}{2}}$ & $\frac{0}{\sqrt[3]{3}}$ & \\
\hline 0 & 20 & 12.5 & 2.5 & 1.25 & 2.5 & - & 38.75 \\
\hline $1 / 2$ & 13.75 & 10 & - & - & 3.75 & - & 27.5 \\
\hline 1 & 15 & 13.75 & - & - & 5 & - & 33.75 \\
\hline 2 & 17.5 & 15 & 1.25 & - & 2.5 & 1.25 & 37.5 \\
\hline 3 & 15 & 12.5 & - & - & 1.25 & - & 28.75 \\
\hline 4 & 12.5 & 11.25 & - & - & - & - & 23.75 \\
\hline 5 & 12.5 & 16.25 & - & - & 1.25 & - & 30 \\
\hline Control & 25 & 27.77 & 7.5 & 10 & 12.5 & 5 & 80 \\
\hline Mean & 15.17 & 13.03 & 0.53 & 0.17 & 2.32 & 0.17 & 31.60 \\
\hline
\end{tabular}

Table.6 Effect of different soaking period in ginger extract on seed mycoflora of okra

\begin{tabular}{|c|c|c|c|c|c|c|c|}
\hline \multirow{2}{*}{$\begin{array}{c}\text { Soaking } \\
\text { period } \\
\text { (hours) }\end{array}$} & \multicolumn{6}{|c|}{$\begin{array}{c}\text { Recorded mycoflora } \\
(\%)\end{array}$} & \multirow[t]{2}{*}{$\begin{array}{c}\text { Frequency } \\
(\%)\end{array}$} \\
\hline & 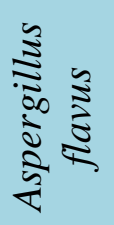 & 离 & 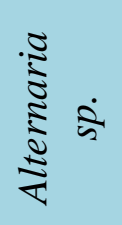 & 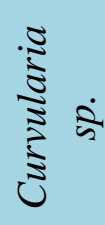 & 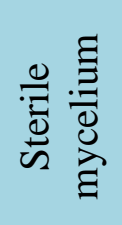 & 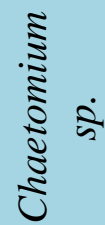 & \\
\hline 0 & 16.25 & 8.75 & 8.75 & 1.25 & - & - & 35 \\
\hline $1 / 2$ & 15 & 13.75 & 3.75 & - & - & - & 32.5 \\
\hline 1 & 12.5 & 13.75 & 6.25 & 2.5 & 1.25 & - & 36.25 \\
\hline 2 & 13.75 & 15 & - & 1.25 & - & - & 30 \\
\hline 3 & 13.75 & 12.5 & 3.75 & - & 2.5 & 2.5 & 35 \\
\hline 4 & 15 & 8.75 & 3.75 & - & - & - & 27.5 \\
\hline 5 & 12.5 & 12.5 & - & 3.75 & - & 1.25 & 30 \\
\hline Control & 27.5 & 22.5 & 15 & 5 & 10 & 7.5 & 87.5 \\
\hline Mean & 14.10 & 12.14 & 3.75 & 1.25 & 0.53 & 0.53 & 32.32 \\
\hline
\end{tabular}




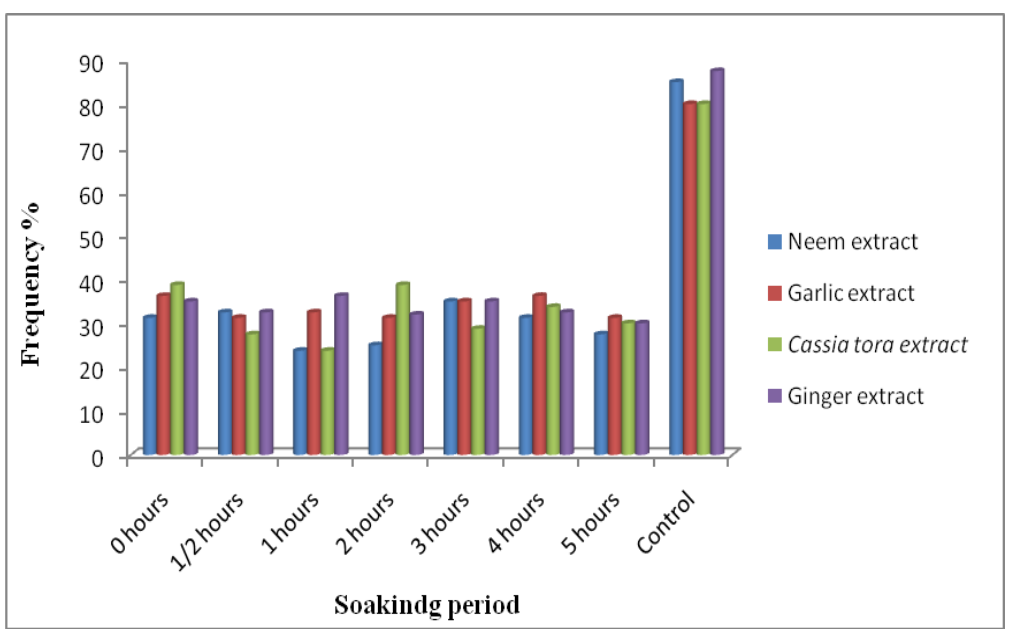

Figure.1 Effect on frequency of mycoflora of different soaking period of seed in botanical extracts

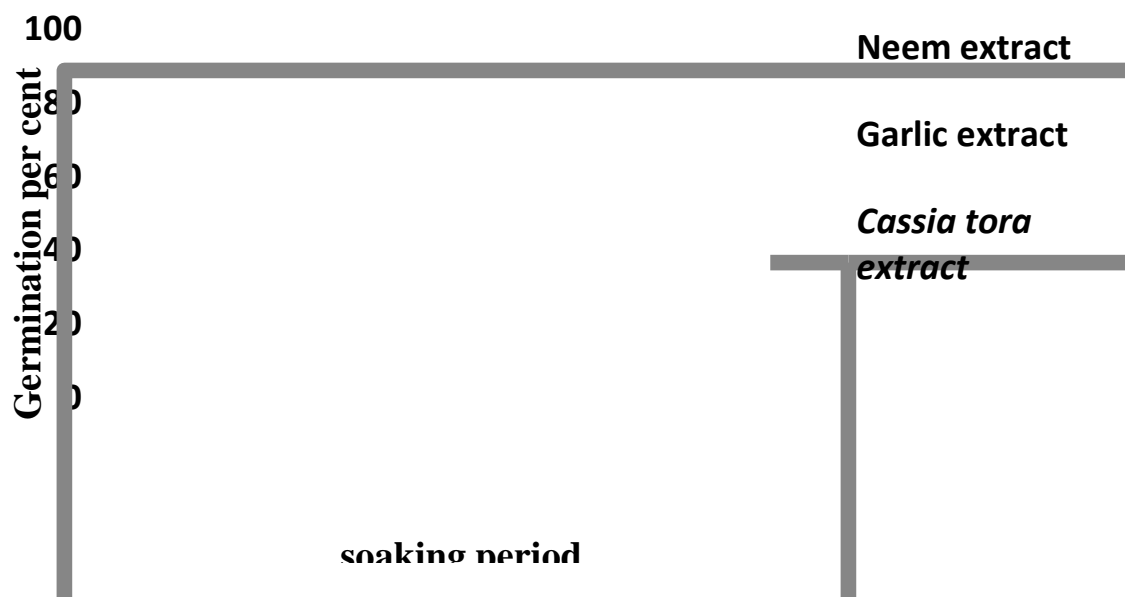

Figure.2 Effect of different soaking period in botanical extracts on seed germination

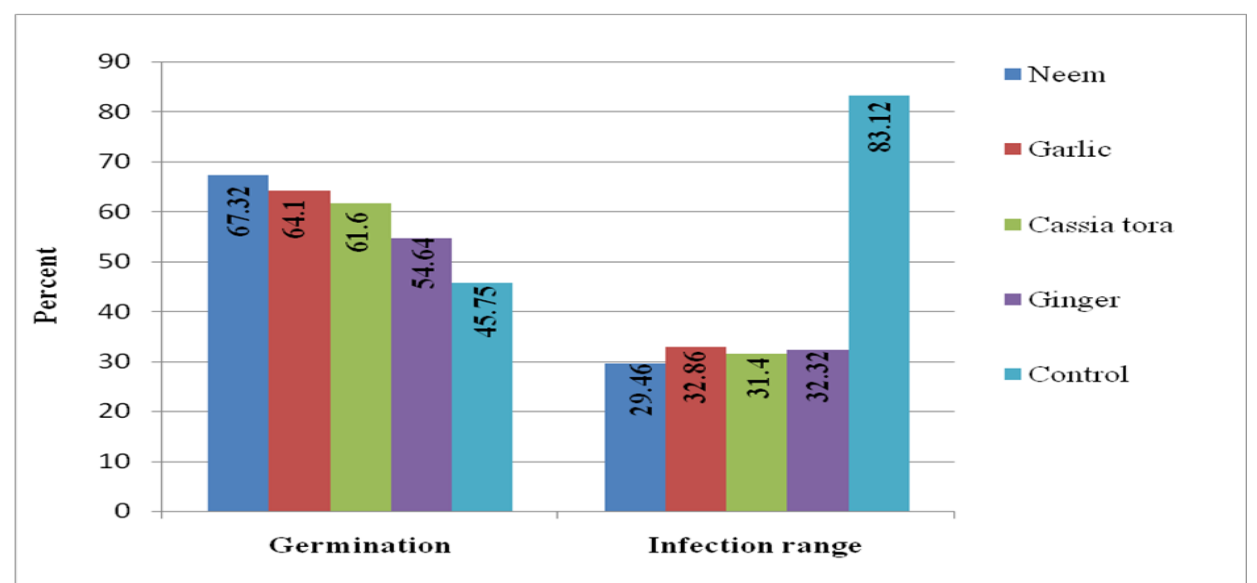

Figure.3 Effect of botanical extract on seed germination and infection range of mycoflora of okra 
Aspergillus flavus was highest $16.25 \%$ in 0 hrs. soaking period followed by $15 \%$ in $1 / 2$ hrs. and 4 hrs. soaking period, $13.75 \%$ in 2 hrs. and 3 hrs. soaking period and lowest 12.5 $\%$ in 1 hrs. and 5 hrs. soaking period, Fusarium sp. was highest $(15 \%)$ in 2 hrs. soaking period followed by $13.75 \%$ in $1 / 2$ and $1 \mathrm{hrs}$. soaking period, $12.5 \%$ in $3 \mathrm{hrs}$. and 5 hrs. soaking period and lowest $8.75 \%$ was in $0 \mathrm{hrs}$. and $4 \mathrm{hrs}$. soaking period, Alternaria $s p$. was highest $(8.75 \%)$ in 0 hrs. soaking period followed by $6.25 \%$ in 1 hrs. soaking period and lowest was $3.75 \%$ in $1 / 2 \mathrm{hrs} .3 \mathrm{hrs}$. and 4 hrs. soaking period and not found in 2 hrs. and 5 hrs. soaking period, Curvularia sp. was highest $(3.75 \%)$ in 5 hrs. soaking period followed by $2.5 \%$ in $1 \mathrm{hrs}$. soaking period and lowest was $1.25 \%$ in $0 \mathrm{hrs}$. and $2 \mathrm{hrs}$. soaking period and not found in $1 / 2 \mathrm{hrs} .3 \mathrm{hrs}$. and $4 \mathrm{hrs}$. soaking period, sterile mycelium was recorded $2.5 \%$ in 3 hrs. soaking period and $1.25 \%$ in 0 hrs. soaking period, Chaetomium sp. was found $2.5 \%$ in $3 \mathrm{hrs}$. soaking period and $1.25 \%$ in 5 hrs. soaking period and not found in 0 hrs., $1 / 2 \mathrm{hrs}$., $1 \mathrm{hrs} .2$ hrs. and $4 \mathrm{hrs}$. soaking period. In control condition frequency was highest of Aspergillus flavus (27.5\%) followed by Fusarium sp. (22.5\%), Alternaria sp. (15\%), sterile mycelium (10\%), Chaetomium sp. (7.5 $\%)$ and lowest was Curvularia sp. (5\%).

Among the Ginger extract on an average Aspergillus flavus (14.10 \%) was highest followed by Fusarium sp. (12.14\%), Alternaria sp. (3.75\%), Curvularia sp. (1.25 $\%)$ and steril mycelium $(0.53 \%)$ and Chaetomium sp. $(0.53 \%)$ was recorded in lowest frequency (Table 6). Similar result was observed by Saha et al., (2014) and Abduhu (2007).

Seed soaking in different duration (hrs.) in ginger extract did not show any significance in controlling microbial frequencies.
Among all different soaking period of plant extracts association of Aspergillus flavus $(8.75 \%)$ was lowest in 2 hour and 5 hour soaking period of neem, Fusarium sp. (7.5\%) was lowest in 1 hour soaking period of neem extract, Chaetomium sp. (1.25\%) was lowest in 5 hour soaking period of ginger extract, 0 hour soaking period of Cassia tora and 2 hours soaking period of neem extract, Alternaria sp. (1.25\%) was lowest in 5 hours soaking period of neem extract, Rhizopus sp. $(1.25 \%)$ was lowest in 3 and 4 hours of neem extract, sterile mycelium $(1.25 \%)$ was lowest in 0 and 3 hour soaking period of garlic extract and Curvularia sp. was eradicated by neem extract.

In conclusion, seed soaking in different duration as seed treatment did not show any significance in controlling microbial frequencies. On an average 3, 4 and 5 hour soaking period was found best seed germination.

\section{Acknowledgement}

The authors are thankful to the Head, Division of Plant Pathology, IGKV, Raipur, C.G. for providing the facility during the course of study.

\section{References}

Abduhu, M., 2007. Quality of okra seed collected from farmers and control of seed borne pathogens by seed treatment. MS Thesis, Department of Plant Pathology. Sher-e-Bangla Agricultural University, Dhaka., pp. iv.

Adams, C. F., 1975. Nutritive value of American foods in common units, U.S. Department of Agriculture, Agric Handbook., 425, pp 29.

Ahmed, N., 2011. Seed borne fungi of lentil and management of stemphylium blight of lentil, M.S. thesis, Dept. of Plant 
Pathology, BAU, Mymensingh pp. 56.

Akter, N., 2008. Effect of plant extract on the management of seed-borne fungal diseases of Okra. M.S. thesis, Dept. of Plant Pathology, BAU, Mymensingh. Pp. 36 \& 74.

Ambekar, J. S., A. S. Pawar and Sakhare, M. V. 2000. Bio efficacy or neem formulations and synthetic insecticides against okra fruit borer. J. Maharashtra Agril. Univ. India. 24 (3): 315-316.

Anonymous, 2004. Garlic tablet in Plant diseases control. A leaflet Published by IPM Lab, Dept. of Plant Pathol., BAU, Mymensingh, Bangladesh.

Anonymous, 2013. Indian Agriculture. Vikas Singhal for Indian Economic Data Research Centre, Maya Puri, New Delhi, India. pp. 271-2.

Anonymous, 2012. United States Nutrient Database laboratory, National Nutrient Database for Standard Reference, Okra raw.

Arapitsas, P., 2008. Identification and Quantification of polyphenolic Compounds from okra seeds and skin. Food Chemical. 110:1041-1045.

Chauhan DVS., 1972. Vegetable Production in India. 3rd ed. Ram Prasad and Sons. Agra,.

Fakir, G. A., 1982. Annual Progress Report. Seed Pathology sub-project. Dept. of Plant Pathol., BAU, Mymensingh. p.17.

Fakir, G. A., 1977. Detection of seed-borne fungi in okra, their role and control. A monograph accepted by the Danish Government Institute of seed Pathology, Copenhagen, Denmark. p. 22.

Fakir, G. A., 2000. An annotated list of seed borne diseases in Bangladesh. Seed Pathology Laboratory, Department of Plant pathology, Bangladesh Agricultural University Mymensingh. pp. 20.

Gupta, K., I. R. Sindhu and Nazz, S. 1989. Seed mycoflora of Abelmoschus esculentus (L.) Mocnch; A survey and enumeration. Acta-Botanica- Indica. 17(2): 200-206.

Hossain, M. M., 2001. Seed-borne fungi and bacteria of cotton and their control. M.S. thesis, Dept. of Plant Pathol., BAU, Mymensingh. pp 47.

I.S.T.A. 1999. International Seed Testing Association. International Rules for Seed Testing. Rules amendments. Seed Science and Technology. 29(2): 1-127.

Islam, M. N., 2004. Efficacy of neem leam extract and ruradan $3 \mathrm{G}$ on soil borne nematodes of okra. MS Thesis, Department of Plant Pathology, Bangladesh Agricultural University (BAU), Mymensingh.

Islam, M. Z., 2006. Effect of seed treatment with mehagoni seed and neem extract on the prevalence of seed-borne pathogens of okra. M.S. thesis, Dept. of Plant Pathol., BAU, Mymensingh. pp. 22-26.

Islam, S., 2012. Health and quality of okra seeds collected from monirampur upazilla of Jessore district and their treatment by plant extracts MS Thesis, Department of Plant Pathology Bangladesh Agricultural University, Mymensingh. pp. 76.

Jamandar, M. M., S. Ashok, J. Shamrao, A. Sajjan and Jahangidar, S. 2001. Studies on seed mycoflora and their effect on germination of color graded okra [Abelmoschus esculentus (L.).

Khaleduzzaman, S. M., 1996. Control of seed borne prevalence by seed treatment in wheat (Tritichum aestivum L.). M.S. thesis, Dept. of Plant Pathol., BAU, Mymensingh, Bangladesh. p. 64.

Moekchantuk, T., and Kumar, P. 2004. Export okra production in Thailand Inter-country Programme for vegetable IPM in South and SE Asia Phase II. Pp. $111-128$.

National Research Council. 2006. "Okra". 
Lost Crops of Africa: Volume II: Vegetables. Lost Crops of Africa.

Neergaard, P., 1979. Seed Pathology, Vol. I.

The Mac Millan Press Ltd., London. p. 839.

Rahman, G. M. M., M. R. Islam and Wadud, M. A. 1999. Seed treatment with plant extracts and hot water. a potential biophysical method of controlling seedborne infection of wheat. Bangladesh J. Training and Development. 12(1-2): $185-190$.

Roy, B., B. C.Sarker, M. R. Ali, S. R. Das, and Sayed, M. A. S. 2012. Seed germination and seedling growth of two vegetables in responses to aqueous extract of four herbal plant leaves. J. Environ. Sci. \& Natural Resour. 5 (1): 141-150.

Saha, S. K., M. A. R. Khokon and Hossain, M. M. 2014. Effects of Plant Extracts on Controlling Seed Borne Fungi of Okra (Abelmoschus esculentus L. Moench). J. Environ. Sci. \& Natural Resources. 7(2): 85-88.

Shekhawat, P. S., and Prasada, R. 1971.
Antifungal properties of some plant extracts. Inhibition of spore germination. Indian Phytopathol. 24(4): 800-802.

Singh, A. K., and Kumar, M. 2003. Efficacy and economics of neem based products against cotton jassid, Amrasca biguttula Ishida in okra. Crop Res. Hisar. 26: 271-274.

Sultana, L., 2009. Assessment of health status of TLS (Truthfully Labeled Seeds) in the markets of Bangladesh. M.S. thesis, Dept. of Plant Pathol. BAU, Mymensingh. p. 39.

Valeriana, P. J., 2002. Training resource text on crop development, major economic practices, disease and insect ecology, insect pests, natural enemies and disease of okra.

Zaman, M. A., A. K. M. Saleh, G. M. M. Rahman and Islam, M. T. 1997. Seedborne fungi of Mustard and their control with indigenous plant extracts. Bangladesh J. Plant Pathol. 13(1\&2): 25-28.

\section{How to cite this article:}

Praveen Banvasi, C.P. Khare, G. K. Awadhiya, Veer Singh, Dheeraj Baghel and Varsha Kerketta. 2020. Effect of Different Soaking Period of Plant Extracts as Seed Treatment to Manage Seed Mycoflora of Okra. Int.J.Curr.Microbiol.App.Sci. 9(05): 1924-1935. doi: https://doi.org/10.20546/ijcmas.2020.905.220 